Универзитет у Нишу

Филозофски факултет

Департман за србистику

\title{
О ПОРЕКЛУ, ИНВЕНТАРУ И ЗНАЧЕЊИМА ПРОСТОРНИХ ЗАМЕНИЧКИХ ПРИЛОГА У СТАРОСЛОВЕНСКОМ ЈЕЗИКУ
}

\begin{abstract}
У раду смо се бавили просторним заменичким прилозима са дијахронијског аспекта. Дате су напомене о њиховој етимологији, као и преглед инвентара и значења ових речи у старословенском језику на основу података које пружа Slovník jazyka staroslovĕnského. Значења просторних заменичких прилога разматрана су у оквиру теорије семантичких локализација, а према подели на заменичкоприлошке локализаторе и заменичкоприлошке квантификаторе, у оквиру које су били релевантни критеријуми говорног лица (код локализатора) и директивности. Кратак преглед значења ових прилога у старословенском језику показао је одређене специфичности овог подсистема заменичких прилога.
\end{abstract}

Клучне речи: просторни заменички прилози, старословенски језик, порекло и значење просторних заменичких прилога, теорија семантичких локализација.

\section{1. Увод}

Заменички прилози се дефинишу као речи са двојаком природом - прилошком и заменичком, одакле потиче термин којим се именују. $^{2}$ Њихова прилошка природа заснива се на функцији одређивања глаголске речи, док се заменичка природа огледа у деиктичности и категоријалности значења (PIPER 1983: 42). Систем заменичких прилога у савременом српском језику описан је у монографијама и радовима П. Пипера (в. STOŠIĆ 2016), а у новије време заменички прилози су били предмет радова Д. Кликовац, С. Кордић и Т. Ашић (в. KORDIĆ 2003; AŠIĆ 2015; KLIKOVAC 2018 и др.). Са историјског аспекта заменичким прилозима бавили су се С. Павловић (2004) и Ј. Стошић $(2019 ; 2020)$. Сви 1 jelena.stosic@filfak.ni.ac.rs

2 O осталим терминима који су фигурирали у науци за заменичке прилоге в.: PIPER 1983: 9-10. 
ти радови на различите начине осветљавају семантику заменичких прилога у различитим периодима развоја српског језика.

Предмет овог рада биће заменички прилози који спадају у семантичку категорију просторних заменичих прилога. Циљ рада је да се укаже на порекло просторних заменичких прилога, да се да̂ њихов инвентар у старословенском језику, као и да се да̂ кратак преглед њихових значења. Деиктичност се код ове семантичке категорије остварује искључиво заменичким кореном који се налази у основи, док код заменичких прилога са осталим категоријалним значењима (времена, начина и др.) постоје и такви заменички прилози који у основи немају заменицу, али се у заменичке убрајају на основу деиктичности и категоријалности значења (PIPER 1983: 42), па се инвентар заменичких прилога проширује прилозима као што су увек, одувек и др.

Познато је да простор спада у основне изворне домене јер човек доживљава свет око себе на основу свог телесног искуства. Просторна значења и њихова улога у концептуализацији света један је од основних постулата когнитивнолингвистички усмерених проучавања. Теорија семантичких локализација сматра се једном од теорија когнитивне лингвистике ${ }^{3}$ с обзиром на то да се заснива на идејама локалистичке теорије, од које се и битно разликује. ${ }^{4}$

Предмет нашег рада били су просторни заменички прилози и њихова значења забележена у чешком речнику старословенског језика Slovník jazyka staroslovĕnského (даље у тексту CJC). ${ }^{5}$ Наиме, евидентирани су просторни заменички прилози, а затим су размотрена њихова значења у оквиру теорије семантичких локализација на основу потврда наведених у CJC. Иако се овом приликом нећемо бавити теоријским поставкама ове теорије, потребно је навести критеријуме према којима ћемо анализирати ексцерпиране заменичке прилоге. За анализу су нам били релевантни кинетички и статички аспект просторног односа, тј. критеријум динамичности и критеријум говорног лица. Према првом критеријуму разликују се следећа семантичка обележја: локативност, аблативност, адлативност и перлативност, док се према другом критеријуму разликују централност, периферност и дисталност. Критеријум говорног лица релевантан је за заменичкоприлошке локализаторе.

Треба навести и поделу заменичких прилога на заменичкоприлошке локализаторе и заменичкоприлошке квантификаторе. Ова подела 3 О томе в. VOJVODIĆ 1998; MEDENICA 2014.

4 О принципима теорије семантичких локализација в.: PIPER 2001: 26-40; MEDENICA 2016.

5 Извори за овај речник су поред канонских старословенских текстова били и редакцијски текстови из каснијег периода. Ми смо разматрали само оне примере који су наведени из канонских споменика. 
заменичких прилога заснива се на томе да ли је примарна функција локализовања у простору или његова квантификација (PIPER 1988: 77).

\section{2. О пореклу просторних заменичких прилога}

Прилози се у граматичкој литератури деле на праве (аутохтоне) и неправе прилоге. Неправи прилози воде порекло од других врста речи, а настали су у процесу адвербијализације или творбе. Поставља се питање где припадају заменички прилози. Браднер (2002: 82-83) претпоставља да су они вероватно образовани пре појаве првих писаних споменика, за шта као доказ наводи чињеницу да су ове речи забележене у текстовима писаним старословенским језиком. Посматрано из дијахронијског угла, просторни заменички прилози настали су додавањем одређених партикула заменичким коренима.

Са савременог становишта, веза између заменичког прилога и заменице одавно није прозирна. У старословенском језику, с друге стране, веза између заменице и заменичког прилога веома се добро чува, мада се већ у тим текстовима могу пратити промене. Разлог за губљење мотивацијске везе између саставних делова заменичког прилога треба тражити у фонетским процесима који су се вршили на почецима стварања самосталних словенских језика. Пре свега је реч о испадању полугласника у слабом положају. Случајеви испадања полугласника у слабом положају могу се пратити и у старословенском језику (в. NIKOLIĆ 2002: 45). Након што се полугласник изгубио у наведеној позицији, у прилозима као што су Къ $\triangle E$ и СЬДE дошло је до гласовних алтернација, које су последица губљења полугласника у слабом положају. На тај начин добили смо облике ГАЕ и $\mathbf{3} А E$. У редакцијама старословенског језика ови су облици могли ठити немотивисани.

Данас се просторни заменички прилози са творбеног аспекта третирају као немотивисане речи (PIPER 1985: 13). Творбеном структуром заменичких прилога у савременим словенским језицима бавио се П. Пипер (1985). Он је утврдио да се код заменичких прилога на формалном плану не може утврдити да потичу од заменица, али се значења парафразирају помоћу придевских заменица, што јасно указује на њихово порекло (PIPER 1985: 15). Пошто је творбена анализа код ових речи отежана, Пипер (1985: 15) наводи да је рашчлањивост ових прилога лакше одредити него њихову мотивисаност. Формална анализа прилога ìge и кyga тако ове речи раздваја на следеће морфеме: i-ge и $\kappa-y g a$, док су оне, историјски посматрано, имале исту основу - заменицу ${ }^{*} k(\mathfrak{b})$.

За просторне заменичке прилоге, посматрано са историјског аспекта, несумњиво се може тврдити да у основи имају заменичке корене, на које су се додавале одређене партикуле. У зависности од значења, 
додаване су следеће партикуле: а) партикула -de; $\delta)$ партикула -mo; в) партикула -dе̌/- $d u .^{7}$

Партикула - de додата на заменички корен по правилу је образовала просторни заменички прилог са значењем мировања.Ова партикула могла је у старословенском језику да гласи и -dе̌ и у питању је млађи старословенски облик (ESSJ2 379). Порекло јата на крају партикуле тумачи се утицајем локатива једнине (ESSJ2 381) јер се њоме исказивало стајање у месту, али се као могућност јавља и утицај адвербијала на -е̌ (ESSJ2 307). Такође се сматра да је облик прилога tu добијен додавањем локативног наставка на заменички корен, при чему је наставак -u наставак некадашње ц̆-промене.

Партикула -то изводи се из инструменталне функције. У етимолошком речнику се као могућност наводи и додавање партикуле -dě/-du на прилог са партикулом -mo, чиме настају прилози типа *kam(o)dě > $k$ ǫdě (ESSJ1 321). ${ }^{8}$

3. Инвентар и значења просторних заменичких прилога у старословенском језику

Како је већ наведено, заменички прилози се деле на заменичкоприлошке локализаторе и заменичкоприлошке квантификаторе. Даљи преглед значења биће дат на основу ове поделе.

\section{1. Заменичкоприлошки локализатори}

У оквиру заменичкоприлошких локализатора релевантна су два критеријума према теорији семантичких локализација: критеријум говорног лица и критеријум директивности. Преглед заменичкоприлошких локализатора биће дат према критеријуму говорног лица, у оквиру чега ће релевантан бити критеријум директивности.

3.1.1. Централност

На лице се код прилога са просторним значењем указује коренском заменичком морфемом (PIPER 1983: 69). Заменички прилози са значењем централности су, према томе, у старословенском језику у основи имали заменицу сь. У српском језику заменица која означава близину

6 Хујер (1935: 102) истиче да се додатак са елементом $d$ јавља често у адвербијалима у индоевропским језицима, а као илустрацију наводи предлоге са додатком $-d \tau$, који су имали просторно значење (нпр. срп. над, под, пред).

7 Наведене партикуле срећу се код просторних заменичких прилога у старословенском језику, а у развоју засебних словенских језика јављале су се и друге партикуле, као и облици ठез крајњег вокала, који је с временом постао покретан (в. RUSÍNOVÁ 1983; BELIĆ 1999: 45 и др.).

8 В. и другачија тумачења у: ESSJ1 375. 
говорнику гласи овај, ова, ово. ${ }^{9}$ У старословенском језику, с друге стране, заменица са кореном ОВ- употребљавала се само у корелацији са другим

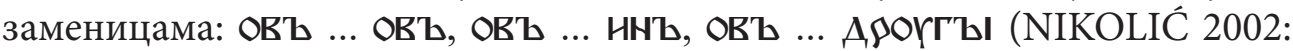
142 ), што важи и за заменичке прилоге који су имали у основи ову заменицу. Прилози са овом заменицом у основи нису имали значење централности (уп. STOŠIĆ 2020: 272).

Примарно значење прилога $\mathbf{C} \mathbf{b} \Delta \mathbf{E}^{10}$ било је локативност. Такво значење остваривало се употребом индирективних глагола. Међутим, у старословенским текстовима забележени су и примери са значењем адлативности, како то показују примери наведени у СЈС. У таквим примерима управна глаголска лексема има значење директивности, тачније носилац је адлативне семнатике, што значи да се овакво значење примарно локативног прилога остварује у контексту. Овај прилог забележен је у контрастној употреби са другим прилозима. У питању су прилози са заменичим кореном ОВ-, Т- и ОN-.

Значење адлативности остваривало се употребом прилошке

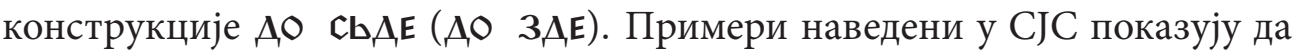
се овај прилог употребљавао уз директивне глаголе. Прилог АО Cь $\Delta$ Е заступљен је само у једном примеру у оквиру лексикографске одреднице, али се још неколико примера може наћи у оквиру одреднице СЬАE. У CJC

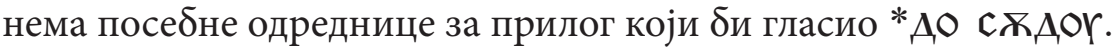

Прилог с Ђно примарно је имао значење адлативности. С обзиром на то је за ово значење карактеристична директивност, глаголи који се употребљавају означавају кретање и носиоци су адлативне семантике, поред прилога. Овај прилог забележен је и у текстуално-деиктичкој функцији.

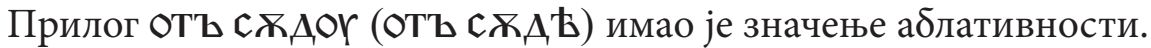
Према примерима наведеним у потврдама, може се закључити да се употребљавао уз директивне глаголе. Као једно од значења јавља се и транспоновано значење порекла, при чему се реферише о нечему што није пореклом са овог света. Даље, забележено је и транспоновано значење узрока.

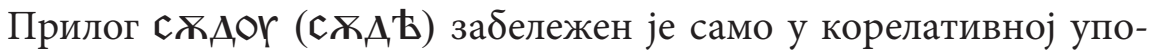

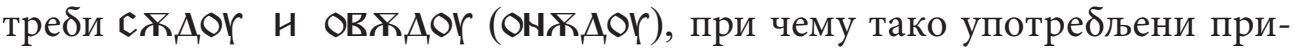
лози имају значење 'на обе стране', 'обострано', 'ту и онде', односно ко-

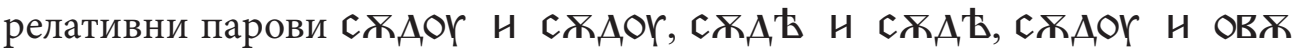

9 Стара заменица са кореном $\mathfrak{C}$ - замењена је заменицом са кореном OB- у старосрпском језику. С. Павловић (PAVLOVIĆ 2004: 218) утврдио је да се заменички прилог овьА са обележјима централности и локативности у старосрпском језику употребљава већ у XIII и XIV веку.

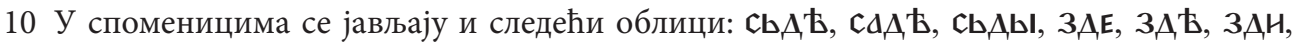
3АЫ, СЕАЕ и др. 
A or са значењем 'са обе стране', 'обострано', 'тамо и овамо'. Дакле, овако употребљени, могли су да се користе и уз директивне и уз индирективне глаголе. У старословенском језику постојао је и посебан прилог са овим значењем - оБо1одог. С обзиром на то да су овим прилогом обухваћене све стране локализатора (тачније обе стране), овај прилог се може сврстати у универзалне квантификаторе. У основи овог прилога налази се заменички број ОБА, а његова се употреба без сумње може довести у везу са употребом двојине у старословенском језику.

\subsection{2. Периферност}

Прилози са значењем периферности подразумевају локализацију у близини саговорника. С тим у вези ови прилози су у основи имали заменицу Тъ.

Да би се значење периферности остварило, потребна је комуникација, што се у тексту може остварити употребом управног говора. Ипак, примећено је да се у текстовима много чешће ови прилози употребљавају у текстуално-деиктичкој функцији. ${ }^{11}$

С обзиром на то да су текстови писани старословенским језиком били текстови црквеног, приповедног карактера, не чуди чешћа употреба прилога са заменичким кореном Т- у наративној функцији.

Са највећим бројем потврда у СЈС заступљен је заменички прилог tou, што може говорити у прилог његовој великој фреквентности у старословенским текстовима. ${ }^{12}$ У СЈC као примарна функција овог прилога наводи се његова наративна функција. Наиме, највише наведених примера односи се на упућивање на места која су већ поменута у претходном контексту. Према критеријуму директивности, овај прилог има значење локативности, али се такође могао употребљавати са глаголима кретања, када је имао значење адлативности. Код таквог значења носилац адлативне семантике је глаголска лексема, па је ово значење, дакле, контекстуално условљено. Тек на другом месту налази се овај прилог са значењем периферности и заступљен је у СЈС мањим бројем примера, од којих немају сви право значење периферности.

У СЈС издвојен је велики број примера употребе прилога тог са глаголима БъТт, ОБљЪстн сА и стоґтн у значењу „постојати”. ${ }^{13}$ Овај

11 О томе в. PIPER 1988: 42; STOŠIĆ: 272-275.

12 C. Кордић (KORDIĆ 2003: 83) утврдила је да је најфреквентнији просторни заменички прилог у савременом језику прилог ту, што је показала и фреквенцијска анализа просторних заменичких прилога у Мирослављевом јеванђељу (STOŠIĆ 2020: 269-270).

13 Т. Ашић (АŠIĆ 2015: 119-125) указује на идиоматску употребу заменичког прилога ту у савременом српском језику у изразу бити ту, при чему он значи, како се наводи, 'ठити присутан'. 
прилог забележен је и са временским значењем, што се наводи под трећим значењем овог прилога.

Прилог ТАно (ТАножАЕ, ТАножЕ) могао је да се употребљава са значењем адлативности и са значењем локативности. Ова значења су контекстуално условљена - право значење прилога, с обзиром на партикулу која је додата заменичком корену, јесте значење адлативности. Међутим, уз глаголску лексему са индирективним значењем, овај прилог имао је локативно значење, које се, ако је судити према броју потврда наведених у CJC, чешће јављало у старословенским текстовима. Када се употребљава са прилогом са значењем цетралности (늩), прилог ТАно има значење 'онај свет', 'живот после смрти'.

Са значењем аблативности употребљавао се прилог отъ Тж Aor(ЖЕ). Примери наведени у оквиру лексикографске одреднице показују да се овај прилог најчешће употребљавао у текстуално-деиктичкој функцији, тј. упућивао је на локалитет који је већ поменут у претходном контексту. Као друго значење наведено је временско значење. С друге стране, временско значење наведено је као примарно прилогу отъTOЛн, отъTоль, ${ }^{14}$ док је за просторно значење наведен само један пример. Овај прилог могао је да има и узрочно значење. Различите транспозиције просторног значења у непросторна значења нису стране ни данас.

За прилог тæдог, тæА⿱ карактеристично је значење перлативности. Носилац перлативне семантике је и глаголска лексема. У CJC наводи се и значење аблативности овог прилога.

\subsection{3. Дисталност}

Прилози са значењем дисталности очигледно нису били нарочито фреквентни, с обзиром на невелик број потврда у СЈС.

Прилог ONЪAE имао је значење локативности. Примери са значењем адлативности нису наведени у CJC. Са значењем локативности наведен је и прилог OHOYAE.

Значење адлативности имао је прилог онdно. У СЈС се наводи контрастивна употреба са прилозима са значењем централности.

Прилог отънждог имао је значење аблативности, док адлативни прилог АО онЖА $\mathrm{b}$ није наведен као засебна одредница у СЈС, али је свакако постојао. ${ }^{15}$

Прилог онжАㅇ забележен је у старословенским текстовима у корелативној употреби, али није забележен самостално.

$14 \mathrm{У}$ СЈС наведени су и прилози ТОЛЬ и дО толЊ. Први прилог упућује на прилог ОТЪ ТОЛН, док је за други наведено само временско значење.

15 B.: ESSJ2: 175. 
Мања заступљеност прилога са значењем дисталности доводи се у везу са честом употребом прилога са заменичким кореном т- у текстуално-деиктичкој функцији.

\section{2. Заменичкоприлошки квантификатори}

Преглед заменичкоприлошких квантификатора биће дат на основу врсте квантификације, а такође ће релевантан бити критеријум директивности.

3.2.1. Универзални квантификатори. Универзални просторни квантификатори афирмативног типа у старословенском језику имали су у основи заменички корен вьс-. Универзални афирмативни квантификатор са значењем локативности у старословенском језику гласио је

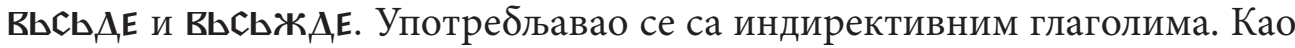

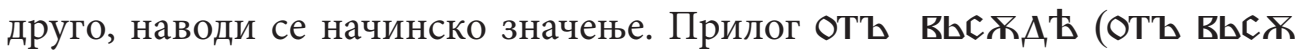
A, or) имао је значење аблативности. Значење аблативности примарно је значење предлога отъ. У универзалне квантификаторе спада и прилог оБовдА

Универзални квантификатор негативног типа у старословенском језику је, као и данас, имао префикс нн-. Са значењем локативности употребљавао се прилог нНКъАЕжЕ. Прилог МнкАно наведен је у СЈС само у облику са партикулом -же, а имао је значење адлативности. Примери наведени уз негативне просторне заменичке прилоге показују да су се тзв. ни-лексеме (в. KOVAČEVIĆ 2002: 16-20) употребљавале и уз негирани предикат и уз глаголску лексему која није негирана. Примери употребе негативних прилога уз ненегиране глаголске лексеме представљају синтаксички грецизам карактеристичан за старословенски језик, а везује се за позицију негативног универзалног квантификатора испред предиката (в. PETKOVIĆ, POLOMAC 2013).

3.2.2. Неодређени квантификатори. Неодређена заменичкоприлошка локализација остваривала се заменичким прилогом нЊКъАЕ. Три наведена примера показују да је овај прилог имао значење локативности. Као посебна одредница у СJC је наведен и прилог нъкهно, али без шире потврде из споменика.

Прилог КъДЕ имао је значење интерогативности, а као друго наводи се неодређено значење. ${ }^{16}$ Употребљавао се са значењем локативности, како показују примери наведени у CJC.

Заменички прилог кАно (КАноже) имао је поред значења интерогативности и значење адлативности. Такође је забележено и неодређе-

16 Овај прилог у српскословенском и старосрпском језику гласио је гА⿱中一. У СЈC указује се на овај облик у српским споменицима писаним старословенским језиком. 
но значење поред упитног.

Значење аблативности имао је заменичкоприлошки квантификатор са упитним значењем оть кж, требљавао се са директивним глаголима. Са индирективним глаголима имао је транспоновано значење порекла.

Уз директивне глаголе употребљавао се прилог кжАㅇ. Наведени примери за употребу овог прилога са упитним значењем углавном показују његово функционисање као везника зависних реченица. С обзиром на значење прилога тæДҺ, и овај прилог примарно има перлативно значење. Као упитни прилог наводи се са транспонованим значењем порекла, када се употребљава са индирективним глаголима.

3.2.3. Релативни квантификатори. Посебних релативних квантификатора није било у старословенском језику. Релативно значење подударности наводи се у CJC код неких просторних заменичких прилога са партикулом. Реч је о прилогу тоrжАE (TorжE TorнжАE) са значењем 'на том истом месту' (уп. PIPER 1988: 133).

3.2.4. Рестриктивни квантификатори. Рестриктивни квантификатори у старословенском језику имали су у основи заменички број ннъ.

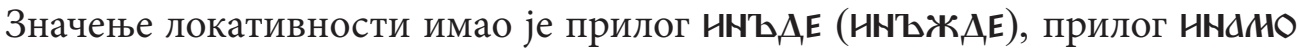

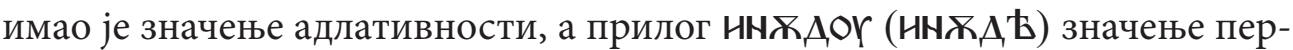
лативности. У СJС се наводе и просторни заменички прилози Аљоггон $\Delta E$ и Аљоггонцн, који су у основи имали Аљогг-, са мањим бројем потврда углавном из каснијег периода.

\section{4. Закључак}

Кратак преглед значења просторних заменичких прилога дали смо на основу речничких дефиниција и потврда из CJC, водећи рачуна о томе да су као извори за састављање овог речника поред старословенских споменика послужили и редакцијски споменици, који потичу из каснијег периода.

Просторни заменички прилози несумњиво су настали додавањем одређених партикула на заменички корен (додавањем партикуле -de настали су прилози са значењем мировања и др.). Претпостављамо да су ови прилози у старословенском језику још увек били мотивисани, а да се њихова веза са заменичким кореном губи у редакцијама под утицајем промена које су захватиле фонолошке системе засебних словенских језика.

Увидом у инвентар, значења и број потврда заменичких прилога у CJC, могу се извући одређени закључци: заменичкоприлошки просторни локализатори били су заступљенији од заменичкоприлошких просторних квантификатора, што не чуди с обзиром на човекову природну 
потребу за пре свега оријентацијом у простору, па тек онда за његовом квантификацијом; заменички прилози са заменичким кореном т- чешће су се употребљавали у текстуално-деиктичкој функцији и били су фреквентни; старословенски језик имао је посебан прилог којим се исказивала универзална квантификација која је подразумевала обухваћеност две стране локализатора, што се могло остваривати и корелативном употребом одговарајућих прилога; примери ослабљене опозиције директивност-индирективност, која се огледа у употреби примарно индирективних прилога са директивним глаголима, може се пратити већ у старословенским текстовима; транспонована употреба просторних прилога забележена је у старословенским текстовима - наведена је њихова употреба са временским, узрочним, начинским значењем и значењем порекла.

\section{Цитирана литература}

AŠIĆ, Tijana. „Spatial deictic expression in Serbian ovde, tamo, tu: a new aproach”. $\mathrm{U}$ : U prostoru lingvističke slavistike (Zbornik naučnih radova. Povodom 65 godina akademika Predraga Pipera). Urednici: Ljudmila Popović, Dojčil Vojvodić, Motoki Nomaći. Beograd, 2015, 111-134.

BELIĆ, Aleksandar. Istorija srpskog jezika. Studije, rasprave, kritike. Izabrana dela Aleksandra Belića, sedmi tom. Beograd: Zavod za udžbenike i nastavna sredstva, 1999. [orig.] БЕЛИТ, Александар. Историја српског језика. Cтудије, расправе, критике. Изабрана дела Александра Белића, седми том. Београд: Завод за уџбенике и наставна средства,1999.

BRADNER, Aleš. „Наречия в кругу частей речи - история их возникновения (образования)", Lingustica brunensia A50, 2002 <https:/digilib.phil.muni. cz/bitstream/handle/11222.digilib/100901/A_Linguistic a_50-2002-1_7. pdf? sequence $=1>19.4 .2021$.

Etymologický slovník slovanských jazyků. Slova gramaticka a zájmena, Svazek 1, ${ }^{17}$ Předložky. Koncové partikule, Academia nakladatelství Československe akademie věd, Praha, 1973.

Etymologický slovník slovanských jazyků, svazek $2,{ }^{18}$ Spojky, častice, zájmena a zájmená adverbia, Academia nakladatelství Československe akademie věd, Praha, 1980.

HUJER, O. Uvod u istoriju slovenskih jezika. Preveo: H. Barić, Beograd, 1935. [orig.] ХУЈЕР, О. Увод у историју словенских језика. Превео: Х. Барић, Београд, 1935.

KLIKOVAC, Duška. „O sistemu zameničkih priloha za mesto u srpskom jeziku: prilog tamo”. U: Srpska slavistika, tom 1. Urednici: Rajna Dragićević, Veljko Brborić, Beograd: Savez slavističkih društava Srbije, 2018, 125-140. [orig.] КЛИКОВАЦ, Душка Б., „О систему заменичких прилога за место у српском језику: прилог тамо”, Српска славистика, том 1, уредници:

17 У раду је коришћена скраћеница ESSJ1.

18 У раду је коришћена скраћеница ESSJ2. 
Рајна Драгићевић, Вељко Брборић. Београд: Савез славистичких друштава Србије, 2018, 125-140..

KORDIĆ, Snježana. „Prilozi ovd(j)/tu/ond(j)e, ovamo/tamo/onamo, ovuda/tuda/ onuda”. Južnoslovenski filolog LIX (2003): 81- 103.

KOVAČEVIĆ, Miloš. Sintaksička negacija u srpskome jeziku. Niš: Filozofski fakultet, 2002. [orig.] КОВАЧЕВИЋ, Милош. Синтаксичка негација у српскоме језику. Ниш: Филозофски факултет, 2002.

MEDENICA, Luka. Nezamenički prilozi sa prostornim značenjem u savremenom ruskom i srpskom jeziku. Neobjavljena doktorska disertacija, 2014. <https:// nardus.mpn.gov.rs/bitstream/handle/123456789/4876/Disertacija510. pdf? sequence=6\&isAllowed=y $>$ 19. 4. 2021. [orig.] МЕДЕНИЦА, Лука. Незаменички прилози са просторним значенем у савременом руском и српском језику. Необјављена докторска дисертација, 2014. <https://nardus.mpn.gov.rs/bitstream/handle/123456789/4876/Disertacija510.pdf?sequence $=6$ \&isAllowed $=\mathrm{y}>19.4 .2021$.

MEDENICA, Luka. „O teoriji semantičkih lokalizacija”. U: Lingvistika i slavistika Predraga Pipera: zbornik radova. Urednik: Dragana D. Jovanović. Novi Sad: Matica srpska, 2016, 27-30. [orig.] Меденица, Лука. „О теорији семантичких локализација”. У: Лингвистика и славистика Предрага Пипера. Зборник радова. Уредник: Драгана Д. Јовановић. Нови Сад: Библиотека Матице српске, 2016: 27-30.

NIKOLIĆ, Svetozar. Staroslovenski jezik I. Pravopis. Glasovi. Oblici. Beograd: Trebnik, 2002. [orig.] Николић, Светозар. Старословенски језик I. Правопис. Гласови. Облиии. Београд. Требник, 2002.

PAVLOVIĆ, Slobodan. „Prostorni prilozi u starosrpskim poveljama i pismima”. Zbornik Matice srpske za filologiju i lingvistiku XLVII/1-2 (2004): 215-231. [orig.] ПАВЛОВИЋ Слободан, „Просторни прилози у старосрпским повељама и писмима”, Зборник Матице српске за филологију и лингвистику XLVII/1-2 (2004): 215-231.

PAVLOVIĆ, Slobodan. „Prostorne metafore u starosrpskim poveljama i pismima”. Zbornik Matice srpske za filologiju i lingvistiku XLVII/1-2 (2014): 215-231. [orig.] ПАВЛОВИЋ, Слободан. „Просторне метафоре у старосрпским повељама и писмима". Зборник Матице српске за филологију и лингвистику XLVII/1-2 (2014): 215-231.

PETKOVIĆ, Jelena, i Vladimir POLOMAC. „Slaganje negacija u starosrpskom jeziku”. Zbornik Matice srpske za filologiju i lingvistiku XVI/2 (2013): 7-22. [orig.] ПЕТКОВИЋ, Јелена и Владимир ПОЛОМАЦ. „Слагање негација у старосрпском језику”, Зборник Матице српске за филологију и лингвистику XVI/2 (2013): 7-22.

PIPER, Predrag. Zamenički prilozi (gramatički status i semantički tipovi). Radovi Instituta za strane jezike i književnosti. A. Jezičke studije, sv. 5, Novi Sad, 1983.

PIPER, Predrag. „О синхронном описании словообразования местоименных наречий в славянских языках”, Južnoslovenski filolog XLI (1985): 13-22. [orig.] ПИПЕР, Предраг. „О синхронном описании словообразования местоименных наречий в славянских языках”. Јужнословенски филолог 
XLI (1985): 13-22.

PIPER, Predrag. Zamenički prilozi u srpskohrvatskom, ruskom i poljskom jeziku (semantička studija). Beograd, 1988. [orig.] ПИПЕР, Предраг, Заменички прилози у српскохрватском, руском и пољьком језику (семантичка студија), Београд, 1988.

PIPER, Predrag. Jezik i prostor. Biblioteka XX vek. Beograd: Čigoja štampa, 2001.

RUSÍNOVÁ, Zdenka. „Slovotvorba staročeských depronominálních adverbiî”. Sborník prací Filozofické fakulty Brněnské university. Studia minora Facultatis philosophicae Untversitatis brunensis A 31, 1983, 51-65.

Slovník jazyka staroslověnského ${ }^{19}$ (red. Josef Kurz), 1-52. Praha: Československá academie vĕd. Slovanský ústav, 1958-1997.

STOŠIĆ, Jelena. „Istraživanja zameničkih priloga u naučnom opusu Predraga Pipera”. U: Lingvistika i slavistika Predraga Pipera: zbornik radova. Urednik: Dragana D. Jovanović. Novi Sad: Matica srpska, 2016: 144-153. [orig.] СТОШИЋ, Јелена. „Истраживаюа заменичких прилога у научном опусу Предрага Пипера". У: Лингвистика и славистика Предрага Пипера: зборник радова. Уредник: Драгана Д. Јовановић, Библиотека Матице српске, 2016: 144-153.

STOŠIĆ, Jelena. Razvoj sistema zameničkih priloga u srpskom književnom jeziku. Neobjavljena doktorska disertacija. Beograd: Filološki fakultet, 2019. $<$ https://nardus.mpn.gov.rs/bitstream/handle/123456789/18088/Disertacija.pdf? sequence $=1$ \&isAllowed $=\mathrm{y}>$ 19. 4. 2021. [orig.] Стошић, Јелена. Развој система заменичких прилога у српском кюижевном језику. Необјављена докторска дисертација. Београд: Филолошки факултет, 2019. <https://nardus.mpn.gov.rs/bitstream/handle/123456789/18088/Disertacija.pdf?sequence $=1$ \&isAllowed $=y>19.4 .2021$.

STOŠIĆ, Jelena. „Prostorni zamenički prilozi u Miroslavljevom jevanđelju”. Crkvene studije 17 (2020): 267-280. [orig.] СТОШИЋ, Јелена. „Просторни заменички прилози у Мирослављевом јеванђељу”. Црквене студије 17 (2020): 267-280.

VOJVODIĆ, Dojčil. „Teorija semantičkih lokalizacija kao univerzalni lingvistički model, Predrag Piper, Jezik $i$ prostor. Beograd: Čigoja štampa (Biblioteka XX vek, 91), 1997, 221 str.”. Južnoslovenski filolog LIV (1998): 204-213. [orig.] ВОЈВОДИЋ, Дојчил, „Теорија семантичких локализација као универзални лингвистички модел, Предраг Пипер, Језик и простор. Београд: Чигоја штампа (Библиотека XX век, 91), 1997, 221 стр.,, Јужнословенски филолог LIV (1998): 204-213.

19 У раду је коришћена скраћеница СJC. 
Елена М. Стошич

\section{О ПРОИСХОЖДЕНИИ, ИНВЕНТАРЕ И ЗНАЧЕНИЯХ МЕСТОИМЕННЫХ НАРЕЧИЙ ПРОСТРАНСТВЕННОЙ СЕМАНТИКИ В СТАРОСЛАВЯНСКОМ ЯЗЫКЕ}

В работе рассматриваются местоименные наречия пространственной семантики с точки зрения диахронии. Приведены примечания об их этимологии, а также обзор инвентаря и значения этих слов в старославянском языке, на основе данных публикации Slovník jazyka staroslovĕnského. Значения местоименных наречий пространственной семантики рассмотриваются с точки зрения теории семантических локализации, согласно ее делении на локализаторов и квантификаторов местоименных наречий, в рамках которой значимыми являются критерии говорящего лица (у локализаторов) и направленности. Краткий обзор значений этих наречий в старославянском языке свидетельствует об определенной специфике этой подсистемы местоименных наречий.

Ключевые слова: местоименные наречия пространственной семантики, старославянский язык, происхождение и значение местоименных наречий пространственной семантики, теория семантических локализации. 